\title{
EFEKTIFITAS IMPLIMENTASI PROGRAM REVITALISASI MGMP SEBAGAI MEDIA MENINGKATKAN KOMPETENSI GURU BAHASA INGGRIS DI KABUPATEN PIDIE
}

\author{
Ramlan $^{(1)}$, Farizawati ${ }^{(2)}$ \\ ${ }^{1,2}$ Program Studi Pendidikan Bahasa Inggris Universitas Jabal Ghafur \\ ${ }^{(1)}$ ramlan@unigha.ac.id, ${ }^{(2)}$ farizawati@unigha.ac.id
}

\begin{abstract}
ABSTRAK
Penelitian ini dilakukan untuk mengetahui sejauh mana efektivitas implimentasi program revitalisasi Musyawarah Guru Mata Pelajaran (MGMP) sebagai media meningkatkan kompetensi guru bahasa inggris. Penelitian ini dimaksud untuk mendapatkan gambaran tentang efektifitas Musyawarah Guru Mata Pelajaran dalam meningkatkan kompetensi guru bahasa Inggris. Tujuan penelitian ini yaitu (1)Menganalisis reaksi setiap peserta terhadap kegiatan Musyawarah Guru Mata Pelajaran bahasa Inggris di Kabupaten Pidie. (2) Mendeskripsikan pengetahuan dan keterampilan mengenai landasan teoritis dan filosofis mata pelajaran bahasa Inggris setelah berpartisipasi dalam kegiatan Musyawarah Guru Mata Pelajaran Bahasa Inggris di Kabupaten Pidie. (3) Menganalisis motivasi setiap peserta kegiatan Musyawarah Guru Mata Pelajaran bahasa Inggris untuk mentransfer pengetahuan dan keterampilan ke dalam proses pembelajaran bahasa Inggris. (4) Menganalisis dampak kegiatan Musyawarah Guru Mata Pelajaran bahasa Inggris terhadap pengembangan kompetensi guru bahasa Inggris di Kabupaten Pidie. Lokasi penelitian ini dilakukan di kabupaten Pidie Provinsi Aceh. Proses penelitian mengikuti langkah-langkah model evaluasi Kirkparick yang meliputi beberapa langkah yaitu reaction, learning, behavior dan results. Langkah pada tahap reaction dilakukan untuk mengetahui kesan atau reaksi setiap peserta apakah peserta merasa senang dan tertarik terhadap implementasi program revitalisasi (MGMP) bahasa Inggris yang dilaksanakan itu. Langkah pada tahap learning dilakukan untuk mengetahui sejauhmana pengetahuan dan keterampilan yang dikuasai oleh setiap peserta selama berpartisipasi dalam program tersebut. Sedangkan tahap berikutnya adalah behavior dilakukan untuk mengetahui apakah setiap peserta program revitalisasi MGMP itu telah mengubah perilaku kinerjanya dengan mengaplikasikan pengetahuan dan keterampilan yang telah dipelajari selama berpartisipasi dalam program itu. Terkahir, fokus evaluasi pada tahap results adalah untuk mengetahui dampak program revitalisai MGMP bahasa Inggris terhadap profesionalisme guru yang ditunjukkan dalam bentuk perbaikan kualitas pembelajaran yang lebih baik. Sampel dalam penelitian ini adalah 30 orang guru bahasa Inggris yang secara aktif telah berpartisipasi dalam program tersebut. Data dikumpulkan melalui teknik kuisioner, wawancara, dan observasi. Hasil penelitian ini diharapkan dapat menganalisis reaksi setiap peserta terhadap kegiatan Musyawarah Guru Mata Pelajaran bahasa Inggris di Kabupaten Pidie, mendeskripsikan pengetahuan dan keterampilan mengenai landasan teoritis dan filosofis mata pelajaran bahasa Inggris setelah berpartisipasi dalam kegiatan Musyawarah Guru Mata Pelajaran Bahasa Inggris di kabupaten pidie, menganalisis motivasi setiap peserta kegiatan Musyawarah Guru Mata Pelajaran bahasa Inggris untuk mentransfer pengetahuan dan keterampilan ke dalam proses pembelajaran bahasa Inggris. menganalisis dampak kegiatan Musyawarah Guru Mata Pelajaran bahasa Inggris terhadap pengembangan kompetensi guru bahasa Inggris di Kabupaten Pidie sehingga penelitian nantinya akan dapat bermanfaat bagi guru bahasa Inggris yang tergabung dalam Musyawarah Guru Mata Pelajaran (MGMP) di Kabupaten Pidie dapat meningkatkan kompetensi guru, mengetahui permasalahan yang dihadapi oleh Musyawarah Guru Mata Pelajaran Bahasa Inggris di Kabupaten Pidie dan alternatif program yang dapat dilakukan untuk mengatasi masalah tersebut. Selanjutnya agar dapat meningkatkan
\end{abstract}


kompetensi guru bahasa Inggris dengan diketahuinya sumber permasalahan utama yang dihadapi guru yang meliputi kompetensi pedagogi dan kompetensi profesionalisme guru.

Kata Kunci: Implimentasi, revitalisasi, MGMP, bahasa Inggris, profesionalisme guru.

\section{PENDAHULUAN}

\section{Latar Belakang Masalah}

Kualitas manusia Indonesia diharapkan mampu menghadapi persaingan yang semakin ketat dengan bangsa lain di dunia, tentu kualitas tersebut dihasilkan melalui penyelenggaraan pendidikan yang bermutu. Seiring dengan tantangan global, pendidikan menjadi sangat penting karena pendidikan merupakan salah satu penentu mutu sumberdaya manusia (SDM). Mutu SDM berkorelasi positif dengan mutu pendidikan, dan mutu pendidikan sering diindikasikan dengan kondisi yang baik, memenuhi syarat, dan segala komponen yang harus terdapat dalam pendidikan. Komponen-komponen tersebut adalah masukan, proses, keluaran, tenaga kependidikan, sarana prasarana serta biaya. Mutu pendidikan akan tercapai apabila masukan, proses, keluaran, guru, sarana dan prasarana serta biaya tersedia dan terlaksana dengan baik. Namun dari beberapa komponen tersebut yang lebih banyak berperan adalah guru yang bermutu atau berkualitas (Sri Damayanti, 2008).

Untuk meningkatkan mutu serta kompetensi guru maka guru perlu memiliki standar profesi dengan menguasai materi serta strategi pembelajaran serta dapat mendorong siswanya untuk belajar sungguhsungguh. Sesuai Undang-Undang Republik Indonesia Nomor 14 Tahun 2005 tentang Guru dan Dosen Pasal 2 ayat (1) menegaskan bahwa guru mempunyai kedudukan sebagai tenaga profesional pada jenjang pendidikan dasar, pendidikan menengah, dan pendidikan anak usia dini pada jalur pendidikan formal yang diangkat sesuai dengan peraturan perundangundangan. Pada Pasal 4 juga dijelaskan bahwa kedudukan guru sebagai tenaga professional sebagaimana dimaksud dalam Pasal 2 ayat (1) berfungsi untuk meningkatkan martabat dan peran guru sebagai agen pembelajaran berfungsi untuk meningkatkan mutu pendidikan nasional.

Di sisi lain, profesionalisme guru di Indonesia masih jauh dari apa yang dicitacitakan hal ini terlihat dari 3,9 juta guru yang ada saat ini, masih terdapat $25 \%$ guru yang belum memenuhi syarat kualifikasi akademik, dan $52 \%$ guru belum memiliki sertifikat profesi. Di sisi lain, seorang guru dalam menjalankan tugasnya harus memiliki standar kompetensi yang mencakup kompetensi pedagogik, kepribadian, sosial, dan professional (Yunus, 2017). Juga berdasarkan hasil tes kompetensi, rata-rata menunjukkan nilai kompetensi guru hanya mencapai 42, $25 \%$, jauh dibawah standar nilai kompetensi minimal yang diharapkan yaitu $75 \%$. Di samping itu menurut Human Development Index (HDI), guru yang memiliki standar kualifikasi mengajar adalah berkisar 60\% untuk SD, $40 \%$ untuk SMP, $34 \%$ untuk SMA. dan 17, $2 \%$ guru mengajar tidak sesuai dengan bidang studi atau latar belakang pendidikannya (Arni Hayati, 2009).

Untuk mengefektifkan program pelatihan guru, tahun 2015 lalu pemerintah melalui Kemendikbud telah melaksanakan UKG dan menetapkan nilai 55,50 sebagai standar kelulusan UKG sebagai pemetaan nilai kompetensi guru se-Indonesia. Guru mata pelajaran bahasa Inggris di Kabupaten Pidie juga telah mengikuti UKG untuk melihat kemampuan guru di kabupaten tersebut. Hasil UKG menunjukkan sebanyak $86 \%$ guru di kabupaten tersebut belum lulus UKG (Dinas pendidikan Pidie, 2015). Data tersebut mengindikasikan bahwa rata-rata kompetensi guru bahasa Inggris di Kabupaten Pidie masih di bawah nilai standar minimal. Sebagai salah satu kota berkembang di provinsi Aceh, sudah seharusnya memiliki guru bahasa Inggris yang memiliki kompetensi profesional dan kompetensi pedagogi yang tinggi, apalagi keberadaan MGMP Bahasa Inggris di Kabupaten Pidie sudah mendapatkan 
pembinaan dari instansi terkait seperti Dinas Pendidikan. Namun demikian, MGMP Bahasa Inggris belum mampu memanfaatkan perhatian dan dukungan tersebut. Kreativitas, vitalitas anggota dan pengurus dinilai masih belum mampu menentukan keberadaan dan pengembangan MGMP Bahasa Inggris itu sendiri. Secara spesifik MGMP diharapkan mampu meningkatkan kompetensi profesional dan pedagogi guru bahasa Inggris di Kabupaten Pidie.

\section{TINJAUAN PUSTAKA}

\section{Pengertian Musyawarah Guru Mata Pelajaran (MGMP)}

Musyawarah Guru Mata Pelajaran (MGMP) merupakan suatu wadah profesional guru mata pelajaran yang berada pada suatu wilayah kabupaten, kota, kecamatan atau sekolah. Prinsip kerjanya adalah kegiatan dari, oleh, dan untuk guru dari berbagai sekolah. Atas dasar ini, maka MGMP merupakan organisasi nonstruktural yang bersifat mandiri, berasaskan kekeluargaan, dan tidak mempunyai hubungan hierarki dengan lembaga lain. Hal ini sejalan dengan Soetjipto dan Raflis (2009: 36) menyatakan bahwa "MGMP merupakan salah satu jenis organisasi guruguru sekolah yang diakui pemerintah sampai saat ini, MPMP didirikan atas anjuran pejabat-pejabat Departemen Pendidikan dan Kebudayaan". Sedangkan (Ondi Saondi dan Aris Suherman, 2010: 80) Wadah komunikasi profesi ini sangat diperlukan dalam memberikan konstribusi pada peningkatan keprofesionalan para anggotanya tidak hanya peningkatan kemampuan guru dalam hal menyusun perangkat pembelajaran tetapi juga peningkatan kemampuan, wawasan, pengetahuan serta pemahaman guru terhadap materi yang diajarkan dan pengembangannya

Melihat pandangan diatas maka bisa kita katakan bahwa MPGP pada hakikatnya adalah peningkatan kemampuan kerja yang dalam manajemen lebih dikenal dengan Program Pendidikan dan Latihan.
Pemerintah juga telah menetapkan tujuan kegiatan MGMP Bahasa Inggris sebagai berikut. (1) Memperluas wawasan dan pengetahuan guru dalam berbagai hal,khususnya penguasaan substansi materi pembelajaran, penyusunan silabus, penyusunan bahan-bahan pembelajaran, strategi pembelajaran, metode pembelajaran, memaksimalkan pemakaian sarana/prasarana belajar, memanfaatkan sumber belajar, mengembangkan kemampuan/profesi guru, dan sebagainya. (2) Memberi kesempatan kepada anggota kelompok kerja atau musyawarah kerja untuk berbagi pengalaman serta saling memberikan bantuan dan umpan balik. (3) Meningkatkan pengetahuan dan keterampilan, serta mengadopsi pendekatan pembaharuan dalam pembelajaran yang lebih profesional bagi peserta kelompok kerja atau musyawarah kerja.(4) Memberdayakan dan membantu anggota kelompok kerja dalam melaksanakan tugas-tugas pembelajaran di sekolah. (5) Mengubah budaya kerja anggota kelompok kerja atau musyawarah kerja (meningkatkan pengetahuan, kompetensi dan kinerja) dan mengembangkan profesionalisme guru melalui kegiatan-kegiatan pengembangan profesionalisme di tingkat MGMP. (6) mutu proses pendidikan dan pembelajaran yang tercermin dari peningkatan hasil belajar peserta didik. (7) meningkatkan kompetensi guru melalui kegiatan-kegiatan di tingkat MGMP

Agar tujuan MGMP dapat tercapai, berbagai langkah perlu ditempuh dalam menentukan bentuk dan proses MGMP (Suyanto, 2013), seperti berikut ini. (a) Penentuan kebutuhan pendidikan dan latihan, atau suatu penilaian yang keutuhan yang komprehensif (b) Penetapan tujuan yang bersifat umum dan spesifik (c) Pemilihan metode (d) Pemilihan media (e) Implementasi program (f) Evaluasi program.

\section{Kerangka Dasar dan Struktur Program MGMP}

Berdasarkan kerangka dasar program kegiatan MGMP merujuk kepada Peraturan 
Menteri Pendidikan Nasional Republik Indonesia No 16 tahun 2007 tentang standard kualifikasi dan kompetensi guru meliputi kompetensi pendagogik, kompetensi kepribadian , kompetensi profesional dan kompetensi sosial. Untuk masing masing kompetensi dapat diuraikan sebagai berikut :

(a). Kompetensi Pendagogik adalah seperangkat kemampuan dan ketrampilan yang berkaitan dengan interaksi belajar mengajar di kelas, bagaimana pemahaman guru terhadap peserta didik, perancangan dan pelaksanaan pembelajaran, pengelolaan kelas, proses evaluasi dalam pembelajaran dan pengembangan peserta didik agar dapat mengaktualisasikan segala kemampuannya dengan maksimal. Adapun indikator dari kompetensi pedagogik ini adalah memahami peserta didik dengan memanfaatkan prinsipprinsip perkembangan kognitif, memahami landasan pendidikan, menerapkan teori belajar dan pembelajaran, menentukan strategi pembelajaran dan menyusun rancangan pembelajaran yang sesuai dengan kondisi peserta didik.

(b). Kompetensi kepribadian adalah seperangkat kemampuan dan karakteristik personal yang mencerminkan realitas sikap dan perilaku guru sebagai tenaga pendidik. Kompetensi kepribadian ini akan melahirkan kepribadian yang mantab, stabil, arif dan berwibawa, beraklaq mulia sehingga menjadi teladan bagi siswa didiknya. Adapun indikatornya antara lain bertindak sesuai dengan norma hukum dan norma sosial, menampilkan kemandirian dalam semua tindakannya sebagai pendidik, semua tindakannya memiliki kemanfaatan bagi peserta didik, sekolah dan masyarakat.

$\begin{array}{lcr}\text { (c). Kompetensi } & \text { profesional adalah } \\ \text { seperangkat } & \text { kemampuan dan } \\ \text { ketrampilan } & \text { terhadap penguasaan }\end{array}$ materi penguasaan secara mendalam, utuh dan koprehensif. Maksudnya guru perlu memiliki penguasaan materi pembelajaran secara luas dan mendalam, mencakup penguasaan materi kurikulum, substansi keilmuan, dan metodologinya. Adapun indikatornya adalah memahami materi ajar yang ada dalam kurikulum sekolah, memahami hubungan konsep antarmata pelajaran yang terkait, memahami langkah-langkah penelitian yang terkait dengan bidang ilmunya.

(d). Kompetensi sosial adalah seperangkat pengetahuan dan ketrampilan yang terkait dengan hubungan atau interaksi dengan orang lain. Dalam kompetensi sosial ini guru dituntut untuk mampu berkomunikasi dan bergaul secara efektif dengan peserta didik, sesama pendidik, orang tua wali murid dan masyarakat sekitar. Adapun indikatornya adalah mampu berkomunikasi dan bergaul secara efektif. Guru adalah sosok elit masyarakat yang dianggap memiliki otoritas moral yang cukup besar sehingga harus memiliki kemampuan berhubungan dan berkomunikasi dengan orang lain.

Keempat kompetensi ini bersifat integratif dan holistik, artinya dalam kemampuan ini harus terintegrasi dalam setiap tindakan dan aktivitas guru secara utuh dan menyeluruh. Sebagai guru profesional harus memiliki keempatnya. Meski demikian, dalam implementasi kurikulum 2013 adalah penguasaan kompetensi pendagogik dan kompetensi profesinal menjadi syarat mutlak yang harus dipenuhi.

Secara spesifik, bagi seorang guru bahasa Inggris, keempat kompetensi di atas harus dimanifestasikan kedalam sejumlah kompetensi komunikatif yang bersifat lebih konkrit Celce-Murcia et al, (1995:5-35). Kompetensi komunikatif itu meliputi (1) kompetensi wacana discourse competence, yaitu kompetensi untuk memahami teks yang dihasilkan dalam suatu peristiwa 
komunikasi nyata dalam konteks tertentu; (2) kompetensi tindak bahasa actional competence, yaitu kompetensi dalam memberikan label sebuah langkah komunikasi dalam bahasa lisan; (3) kompetensi linguistik linguistic competence, yaitu kompetensi untuk menguasai berbagai komponen (tata bahasa, fonologi, pelafalan, kosa kata, dsb) dan karakteristik bahasa Inggris; (4) kompetensi sosial budaya sociocultural competence, yaitu penguasaan tata cara atau etika berkomunikasi dalam bahasa Inggris; dan (5) kompetensi strategis strategic competence, yaitu kompetensi yang berkaitan dengan strategi komunikasi yang efektif (lisan atau tulis) dalam konteks tertentu. Lima kompetensi ini sangat berperan dalam mendukung guru bahasa Inggris terutama dalam mengaplikasikan bahasa Inggris sebagai alat komunikasi sehari-hari colloquial language maupun komunikasi dalam dunia ilmiah scientific language secara wajar sesuai dengan cara native speaker of English berkomunikasi. Selain itu, kompetensi komunikatif tersebut berimplikasi pada bagaimana seorang guru bahasa Inggris harus mengajarkan bahasa tersebut kepada setiap peserta didik.

Pengetahuan tentang tata bahasa yang benar dapat membantu guru memonitor dan mengoreksi dirinya sendiri dan peserta didik dalam proses komunikasi. kompetensi strategis akan mengarahkan guru bahasa Inggris untuk mampu menciptakan proses pembelajaran yang menyenangkan dan menarik bagi siswa. Di lain sisi, kompetensi sosiolinguistik dapat membantu guru bahasa Inggris melatih peserta didik untuk berkomunikasi menggunakan tata bahasa dan pilihan kata sesuai konteks sosial tertentu.

\section{Kompetensi Guru bahasa Inggris}

Kompetensi diartikan sebagai pengetahuan, keterampilan, dan nilai-nilai dasar yang direfleksikan dalam kebiasaan berpikir dan bertindak. Arti lain dari kompetensi adalah spesifikasi dan pengetahuan, keterampilan dan sikap yang dimiliki seseorang serta penerapannya di dalam pekerjaan, sesuai dengan standar kinerja yang dibutuhkan di lapangan. Sedang yang dimaksud dengan kompetensi guru teacher competency merupakan kemampuan seorang guru dalam melaksanakan kewajiban secara bertanggung jawab dan layak. Menurut Hamzah B. Uno (2008: 28), ada beberapa kemampuan yang dituntut dari guru agar dapat menumbuhkan minat dalam proses pembelajaran, yaitu :

1. Mampu menjabarkan bahan pembelajaran ke dalam berbagai bentuk cara penyampaian.

2. Mampu merumuskan tujuan pembelajaran kognitif tingkat tinggi, seperti analisis, sintesis, dan evaluasi. melalui tujuan tersebut maka kegiatan belajar peserta didik akan lebih aktif dan komprehensif.

3. Menguasai berbagai cara belajar yang efektif sesuai dengan tipe dan gaya belajar yang dimiliki oleh peserta didik secara individual.

4. Memiliki sikap positif terhadap tugas profesinya, sehingga selalu berupaya untuk meningkatkan kemampuan dalam melaksanakan tugasnya sebagai guru.

5. Terampil dalam membuat alat peraga pembelajaran sederhana sesuai kebutuhan dengan tuntutan mata pelajaran yang dibinanya serta penggunaannya dalam proses pembelajaran.

6. Terampil dalam menggunakan berbagai model dan metode pembelajaran yang dapat menumbuhkan minat sehingga hasil belajar optimal.

7. Terampil dalam melakukan interaksi dengan peserta didik dengan mempertimbangkan tujuan dan materi pelajaran, kondisi peserta didik, suasana belajar, jumlah peserta didik, waktu yang tersedia, dan faktor yang berkenaan dengan diri guru itu sendiri.

8. Memahami sifat dan karakter peserta didik, terutama kemampuan belajarnya dan kebiasaan belajar, minat terhadap pelajaran, motivasi untuk belajar, dan hasil belajar yang telah dicapai. 
9. Terampil dan menggunakan sumbersumber belajar yang ada sebagai bahan ataupun media belajar bagi peserta didik dalam proses pembelajaran.

10. Terampil dalam mengelola kelas atau memimpin peserta didik dalam belajar sehingga belajar menjadi menarik dan menyenangkan

Dengan demikian kompetensi yang dimiliki oleh setiap guru akan menunjukan kualitas guru yang sebenarnya. Kompetensi tersebut akan terwujud dalam bentuk penguasaan pengetahuan, keterampilan maupun sikap professional dalam menjalankan fungsi sebagai guru serta kemampuan melaksanakan tugas-tugas yang menjadi tanggung jawab guru yang merupakan sebagian dari kompetensi profesionalisme guru.

Berdasarkan beberapa pendapat para ahli tersebut dapat disimpulkan tentang tugas guru yaitu (a) tugas pengajaran, bimbingan dan latihan kepada siswa, (b) pengembangan profesi guru, (c) pengabdian masyarakat. Untuk dapat melaksanakan tugas dan tanggung jawab di atas, seorang guru dituntut memiliki beberapa kemampuan dan keterampilan tertentu.

\section{METODE PENELITIAN}

\section{Lokasi Penelitian}

Penelitian ini akan dilaksanakan di Kabupaten Pidie Provinsi Aceh, hal ini dikarenakan Kabupaten Pidie merupakan salah satu kota yang sedang berkembang dan kota yang bergantung pada kualitas SDM yang memiliki lulusan sekolah dengan kemampuan berkomunikasi yang baik dalam bahasa Inggris yang merupakan tujuan pemerintah dalam program mewujudkan Aceh Carong (Aceh cerdas), salah satu program prioritas Gubernur Aceh dalam bidang pendidikan yaitu peningkatan mutu dan kota cerdas yang dicanangkan dalam misi kerja Kabupaten Pidie. Hasil penelitian ini diharapkan mampu membantu pemerintah Aceh dalam mengahadapi persaingan Masyarakat Ekonomi Asia (MEA). Kemudian keberadaan MGMP guru bahasa Inggris di Kabupaten Pidie sudah dilaksanakan selama beberapa tahun terakhir.

\section{Metode Penelitian}

Metode penelitian yang diterapkan dalam penelitian ini adalah penelitian evaluatif. Menurut (Arikunto 2007: 222) penelitian evaluatif dapat diartikan suatu proses yang dilakukan dalam rangka menentukan kebijakan dengan terlebih dahulu mempertimbangkan nilai-nilai positif dan keuntungan suatu program, serta mempertimbangkan proses serta teknik yang telah digunakan untuk melakukan suatu penelitian. Artinya data yang dikumpulkan bukan berupa angka-angka saja, melainkan data tersebut berasal dari catatan lapangan (observasi), wawancara (analisis dokumentasi) dan kuesioner.

\section{Teknik Pengumpulan Data}

Proses penelitian evaluatif ini mengikuti empat tahap evaluasi Kirpatrick (1996:21) yang meliputi evaluasi terhadap reaction, learning, behavior dan results. Evaluasi pada tahap reaction dilakukan untuk mengetahui kesan atau reaksi setiap peserta apakah peserta merasa senang dan tertarik terhadap program MGMP bahasa Inggris yang dilaksanakan itu. Evaluasi pada tahap learning dilakukan untuk mengetahui sejauh mana pengetahuan dan keterampilan yang dikuasai oleh setiap peserta selama berpartisipasi dalam kegiatan MGMP tersebut. Sedangkan evaluasi behavior dilakukan untuk mengetahui apakah setiap peserta MGMP itu telah mengubah perilaku kinerjanya dengan mengaplikasikan pengetahuan dan keterampilan yang telah dipelajari selama berpartisipasi dalam kegiatan MGMP Bahasa Inggris itu. Terkahir, fokus evaluasi pada tahap results adalah untuk mengetahui dampak kegiatan MGMP bahasa Inggris terhadap peningkatan kompetensi guru yang ditunjukkan dalam bentuk peningkatan kemampuan penguasaan materi ajar dan perbaikan kualitas pembelajaran yang lebih baik. 


\section{Analisa Data}

Seperti telah dijelaskan di muka bahwa kajian/penelitian evaluatif ini dimaksudkan untuk mengetahui efektivitas kegiatan MGMP bahasa Inggris SMPN2 guna meningkatkan kompetensi para guru bahasa Inggris sehingga kualitas penguasaan materi ajar dan praktik pembelajaran di kelas menjadi semakin baik. Sesuai dengan karakteristik kegiatan tersebut, penelitian evaluatif ini mengaplikasikan model empat tahap evaluasi Kirkpatrick (Kirpatrick"s Four-level Evaluation Model). Variable yang menjadi fokus dalam kajian ini meliputi reaksi guru terhadap pelaksanaan kegiatan MGMP, pengetahuan dan keterampilan guru setelah mengikuti kegiatan MGMP, motivasi guru untuk menstranfer pengetahuan dan keterampilan, serta dampak kegiatan MGMP terhadap peningkatan kometensi guru.

Secara eksplisit, hubungan antarvariabel dalam penelitian ini dapat digambarkan sebagai berikut:

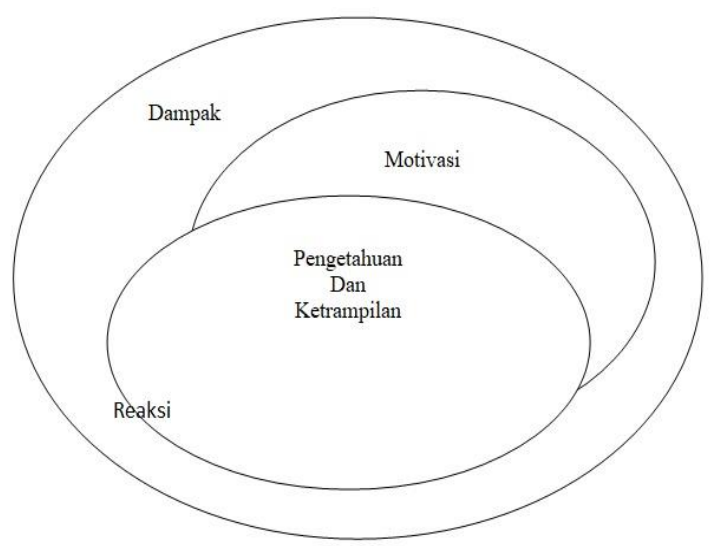

Data dalam penelitian ini dikumpulkan melalui tiga teknik yang berbeda, yaitu kuesioner, observasi, dan wawancara. Data yang didapatkan kemudian diuji dengan menggunakan analisis regresi. Untuk menentukan apakah ketiga variabel antiseden tersebut mempengaruhi dampak kompetensi guru atau tidak, analisis regresi dilakukan dengan mengikuti prosedur yang terdiri dari empat langkah. Empat persamaan regresi digunakan untuk menguji tata hubungan antarvariabel dalam penelitian ini. Selain itu analisis korelasi antarvariabel juga diamati untuk mengetahui besarnya koefisien korelasi antarvariabel tersebut.

\section{Hasil}

Kemajuan hasil penelitian menunjukkan sudah mencapai 60 persen, reaksi positif setiap partisipan/peserta terhadap implementasi program tersebut secara signifikan telah mampu mempengaruihi terjadinya peningkatan pengetahuan dan keterampilan bagi setiap partisipan/peserta program tersebut mengenai landasan filosofis dan teoritis pembelajaran bahasa Inggris dikabupaten Pidie. Namun demikian, peningkatan pengetahuan dan keterampilan itu tidak serta merta membawa dampak yang signifikan pada tataran praktis, yaitu kualitas proses pembelajaran yang dilakukan oleh guru, peserta program revitalisasi MGMP itu, di kelas. Guru-guru masih cenderung menggunakan pola-pola konvensional dalam melakukan proses pembelajaran bahasa Inggris.

\section{Keimpulan}

Kesimpulan Hasil penelitian evaluatif pada implementasi program revitalisasi MGMP dalam bahasa Inggris menunjukkan bahwa respon positif dari masing-masing peserta terhadap implementasi program telah mempengaruhi tingkat penguasaan pengetahuan dan keterampilan yang dikuasai oleh masing-masing peserta. Namun, perolehan pengetahuan dan keterampilan tidak serta merta berdampak signifikan pada kualitas proses pembelajaran yang dilakukan oleh peserta dalam program revitalisasi MGMP.

\section{Daftar Pustaka}

Arikunto, Suharsimin. (2007). Manajemen

Pendidikan. Jakarta:PT Rineka

Cipta.

Arni Hayati, dkk. (2009). Guru Bermutu Pendidikan Juga Bermutu. www.Fai.Uhamka.ac.id 
Celce-Murcia, M., Dornyei, Z., \& Thurrell, S. (1995). Communicative Competence: A Pedagogically Motivated Model with Content Specifications. Issues in Applied Linguistics 6; 2; pp. 5-35

Depdiknas. (2005). Undang-undang nomor 14, tahun 2005, tentang Guru dan Dosen.

Fasli Jalal. (2005) Teachers' Quality Improvement in Indonesia: New Paradigm and Milestones. Jakarta: Departemen Pendidikan Nasional.

Saondi, Ondi dan Suherman, Aris. (2010). Etika Profesi Keguruan, PT Refika Aditama:

Bandung.

Sugiyono. (2007). Metode Penelitian Pendidikan: Pendekatan Kuantitatif, Kualitatif, dan $R \& D$. Bandung: Alfabeta.
Soetjipto, \& Raflis, K. (2009). Profesi

Keguruan. Jakarta: Rineka Cipta.

Uno, Hamzah B. (2007). Model Pembelajaran Menciptakan Proses Belajar Mengajar yang Kreatif dan Efektif. Jakarta: Bumi Aksara

Undang-undang Republik Indonesia Nomor 20 tahun 2003. Tentang Sistem pendidikan nasional.

Peraturan Pesiden Nomor 87 Tahun 2017 tentang penguatan pendidikan karakter

Website:

http://www.definisipengertian.com/2015/05/definisipengertian-kompetensi-pendidikanguru.html di akses 22/04/2019 jam $\underline{04.13}$ 